\title{
Çağdaş Sanatta Bireyin Kent ve Tüketim Fenomenleri Üzerinden Eleştirisi
}

\section{The Criticism of The Individual in Contemporary Art through The City and Consumption Phenomenes}

\section{Melike Nükte Dinçer}

Öğr. Gör., Necmettin Erbakan Üniversitesi, Güzel Sanatlar ve Mimarlık Fakültesi, Seramik Bölümü

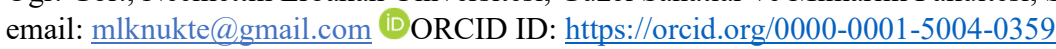

\section{Funda Susamoğlu Ertürk}

Doç., Hacettepe Üniversitesi, Güzel Sanatlar Fakültesi, Seramik ve Cam Tasarımı Bölümü email: fundasusam@gmail.com (DORCID ID: https://orcid.org/0000-0002-7828-5574

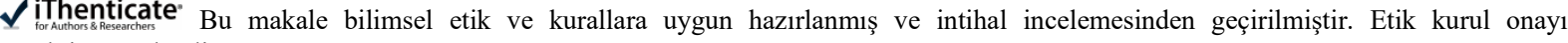 \\ gerektirmemektedir. \\ Atıf (APA 7)/To cite this article \\ Dinçer, M. N., \& Susamoğlu Ertürk, F. (2021). Çağdaş sanatta bireyin kent ve tüketim fenomenleri üzerinden eleştirisi. Atatürk Üniversitesi \\ Güzel Sanatlar Enstitüsü Dergisi, 27(47), 570-581. https://doi.org/10.35247/ataunigsed.980823 \\ Makale Gönderim Tarihi/Received: 09/08/2021 \\ Makale Kabul Tarihi/Accepted: 26/09/2021 \\ Makale Yayın Tarihi/Published: 28/10/202
}

Review Article / Derleme Makale

Öz

Modern çağın en önemli olgularından biri olan birey idealinin tarihsel olarak dönüşümü, birçok alanda olduğu gibi sanat alanında da ifade bulmuștur. Kentlessme ve tüketim olgularının modern çağa dayanan tarihi, sanatta halen eleştirel bir tavırla varlığını sürdürmektedir. Kentlesme ve tüketim kültürünün, hem bireyin dönüşümünde hem de gündelik yaşamda etkilerinin büyük olduğu söylenebilir. Çağımızın tüketim nesnelerinin artan dolașımı, bireyin mutluluk arayıșında tüketime başvurduğu yaygın bir eğilim olarak karşımıza çıkmaktadır. Arzuların ve mutluluğun tüketim kültürünün sınırlarına indirgenmesi; bireyi piyasanın tüketim sarmalı içinde bir veriye dönüştürmektedir. $\mathrm{Bu}$ bağlamda sosyal ve aile ilişskilerinin değişimi, bireysel yaşamı değersizleștirirken nesnelerin değer kazanması ve bireyin yalnızlaşması gibi durumlar ortaya çıkmaktadır.

Bu makalede, bireyin yașadığı duygusal gerilimin kent ve tüketim fenomenleri çerçevesinde, çağdaş sanatta örnekler üzerinden irdelenmesi amaçlanmaktadır. Ele alınan sanatçılar, çağın değişken koșulları karşısında bireyin yaşadığ 1 sorunlara farklı yaklaşımları göz önünde bulundurularak tartışılmaktadır.

Anahtar kelimeler: Sanat, Çăgdaș Sanat, Birey, Kent, Tüketim

\begin{abstract}
The historical transformation of the ideal of the individual, which is one of the most important events of the modern age, has found expression in art as well as in many fields. The history of urbanization and consumption phenomena, which are dating back to the modern age, still maintains its existence in art with a critical attitude. It can be said that urbanization and consumption have great effects both on the individual and in daily life. The increasing circulation of consumption objects in our age is a common trend in which the individual resorts to consumption in search of happiness. Reducing desires and happiness to the limits of consumption culture; transforms the individual into data in the consumption spiral of the market. In this context, situations such as the change of social and family relations, devaluation of individual life, the appreciation of objects, and the isolation of the individual occur.

This article aims to discuss the emotional tension experienced by the individual through examples from contemporary art, which examines the urban and consumption phenomena. It is discussed by considering the different approaches of the artists to the problems experienced by the individual in the face of the changing conditions of the age.
\end{abstract}

Keywords: Art, Contemporary Art, Individual, City, Consumption

\section{Giriş}

Aydınlanma çağıyla birlikte yükselen birey kavramı, ilerlemecilik anlayışıyla insanlık için büyük bir değişim olarak kabul edilmektedir. Bu değişim bireyin kendini bir değer olarak belirlemeye başlamasıyla ortaya çıkmaktadır. Rönesans öncesi toplumlarda; bireyin hayatını, eylemlerini, esas isteklerini; ailesinin, içinde bulunduğu toplumun veya dinin belirlediği söylenebilir. Ancak birey kavramının doğuşuyla; insanın kendisine bakış açısı değişmiş ve yeni bir insan anlayışı ortaya çıkmıştır. "Aydınlanma, Kant'ın deyişiyle, insanın kendi suçu ile düşmüş olduğu bir ergin olmama durumundan kurtulmasıdır” (Adorno ve Horkheimer, 2014, s. 115). Ancak Aydınlanma projesinin düşünüldüğü gibi sonuç vermemesi ve ardından gelişen tarihsel ve sosyal olaylar, birey ideali eleştirisini karşımıza çıkarmaktadır.

Bireycilik ideolojisi, sanayileşme, kentleşme, teknoloji ve tüketimin yükselişiyle kademeli bir şekilde gelişmiştir. Alaman sosyolog Ulrich Beck'e göre bireycilik; sınıf/sosyal statü, cinsiyet rolleri, aile, komşuluk gibi kategorilerin önceden var olan biçimlerini parçalamıştır. Beck, bu tür sosyal formların artık olmadığı anlamına gelmediğini fakat bireyin artık öteki insanların yaşamlarıyla daha az ilgilendiğini belirtmektedir (Beck ve Beck-Gernsheim 2002, s. 2-6). 
Toplumsal, siyasal, ekonomik ve kültürel alanlarda yaşanan değişimlerin temelinde, bireyin daha iyi bir geleceğe ilerlediği inancı yatmaktadır. Alaman sosyolog Georg Simmel, modern çağa duyulan inancı "Yeni bir ideal vardı: Bireyin özgürleşmesi, hayatın akılcı hale gelmesi, insanın mutluluk ve kusursuzluk yolundaki kesin ilerleyişi" sözleriyle ifade etmektedir (Simmel, 2019, s. 58). Peki, modern çağın insanlığa daha iyi bir gelecek sunduğu söylenebilir mi?

Elbette her çağ öncekilerine göre ilerleme kaydetmektedir, fakat her ilerlemenin insanlığa mutluluk ve refah sağlamadığ 1 tarihsel süreç içerisinde gözlemlenebilir. Alain Touraine "Modernliğin Eleştirisi" kitabında, Aydınlanmanın "akılcı" düşünce yapısının, bireyin mutluluğunu, özgürlüğünü ya da gereksinimlerini hangi anlamda karşıladığını ele almaktadır. Touraine, geleneksel otorite biçimlerinin serbestlik kazanmasının bireyi özgürlüğe davet ettiğini ancak onu aynı zamanda üretimin ve tüketimin merkezi örgütlenmesine tabi kıldığını ifade eder. Modern çağı, tüketim ve iletişim dünyasına doğru normalleştirme ve standartlaştırma çabası olarak görmektedir. "Bu modernlik, öznenin özgürlüğünü davet ettiğinde bile -hatta bu durumda daha da fazla- tek tek insanların, bütünün -o bütün, ister işletme olsun, ister ulus, ister toplum ya da bizzat aklın kendisi- çıkarlarına boyun eğmesini amaçlar" (Touraine, 1995, s. 13-23).

Albert Berman'a göre; “Modern olmak, bizlere serüven, güç, coşku, gelişme, kendimizi ve dünyayı dönüştürme olanakları vaat eden; ama bir yandan da sahip olduğumuz her şeyi, bildiğimiz her şeyi, olduğumuz her şeyi yok etmekle tehdit eden bir ortamda bulmaktır kendimizi” (Berman, 2013, s. 27). Modernizmin özgürlük, eşitlik ve mutluluk vaatleri beklenilen sonucu yaratmadığ görünür hale gelmektedir. Modern çağın pazara verdiği önem, toplumu ve bireyi indirgemiş dolayısıyla birey kendini güvensiz, çaresiz ve bir telaş içinde bulmuştur.

19. yüzyılda gelişen Romantizm akımı modernliğe karşı söylemlerin ilk örneklerinden biri olarak gösterilebilir. Michael Löwy ve Robert Sayre'nin "İsyan ve Melankoli” kitabında Romantizmin özü şu şekilde belirtilir: "Bize göre, romantizm; modernitenin yani modern kapitalist uygarlığın, geçmişteki (pre-kapitalist, pre-modern) değer ve idealler adına eleştirisini temsil eder" (Löwy ve Sayre, 2015, s. 33). Bu ifadeden yola çıkarak romantizmin özünün kapitalizme karşı bir tepki olduğu söylenebilir. Löwy ve Sayre'ye göre; kapitalizmin olumsuzluğu, toplumun bölünmesi ve insan ilişkilerinin cansız nesneler arasındaki ilişkilere dönüştürmesidir (Löwy ve Sayre, 2015, s. 37).

Bireyciliğin gizli tarafının ben üzerine odaklanması; kişinin yalnızlığına, hayatın yavanlaşmasına, çevresindeki kişilere ve olaylara ilginin azalmasına sebep olabilmektedir. Bireyin bu durumu aynı zamanda "araçsal aklın" öncelik kazanmasıyla ilişkilidir. Araçsal akıldan kastedilen her şeyin bir amaca ulaşmak için kullanıma açık hale gelmesidir. Değerler, inançlar ve hatta ilişkiler bile bir başka amaca hizmet eden araçlardır. "Araçsal (öznel) akıl Adorno'ya göre dünyadaki her şeyi global alış-verişin bir eşyası haline getirmiştir. Bireyin de doğadaki diğer şeyler gibi bir eşyaya indirgenmesi, Adorno ve Horkheimer'a göre aklın bugünkü bunalımının gerçek sebebidir" (Karamolla ve Kiriş Yılmaz, 2020, s. 3569).

Modern çağa damgasını vuran kentleşme ve tüketim gibi olguların bireyin dönüşümünde etkileri büyüktür. Gündelik yaşamla ilgili bireysel deneyimimizin bir ömür içinde önemli ölçüde değiştiği söylenebilir. Hayat mücadelesi giderek zorlaşmakta ve bireyin iç dünyasıyla gerçekler arasında yaşadığ mutsuzluğu ve tek düze yaşam biçimini getirebilmektedir. Dolayısıyla birey kendini dış dünyaya daha çok kapatmakta ve gündelik rutini içinde varoluş mücadelesini kalabalıklar içinde yalnız sürdürmektedir. Sonuç olarak bireyin eleştirisi sanat aracılığıyla kentleşme ve tüketim olguları üzerinden tartışılmaktadır. Bu olguların çağdaş sanata yansımaları 1990 sonrasından günümüze kadar üretilen eserler üzerinden incelenmektedir. Konuya ilişkin farklı yaklaşım ve sanat pratikleriyle Andrea Zittel, Liu Bolin, Grayson Perry ve David Bianchi'nin eserleri ele alınmaktadır. Ayrıca kişisel uygulama üzerinden konuya dair bir proje gerçekleştirilmiştir.

\section{Yöntem}

Bu araştırma, çağdaş sanatta bireyin kentleşme ve tüketim fenomenleri üzerinden eleştirilmesinin irdelendiği nitel bir araştırmadır. Makale kapsamında konu ile ilgili bir uygulama projesi, görsel analizler, okumalar, ve literatür taraması yapılarak veri toplandıktan sonra, çağdaş sanat kapsamında sanatçıların eserleri ve kişisel proje üzerinden tüketim ve kentleşme olgularının birey üzerindeki etkileri tartışılmıştır.

\section{Bulgular ve Yorum}

\subsection{Kentin Çıkmazları}

Georg Simmel, "Modern Kültürde Çatışma” adlı kitabında metropolü, kalabalığın toplumsal mekânı olarak tanımlamaktadır. Metropol olgusu üzerinden, kentin karmaşasını, bireyin gündelik yaşamını ve yalnızlı̆̆ını incelemiştir. Kalabalık nüfusun oluşturduğu kentte bireyin neden daha fazla yalnızlaştığı üzerine yazar; metropolün sürekli değişen yapısından dolayı kişilerin çevresine duyarsızlaştığından söz etmektedir. Bu durumu "Metropol kişilik tipinin ruhsal temelini, sinirsel uyarıcıların yorgunluğu oluşturur. Bu, iç ve dış uyarıcılardaki 
hızlı, kesintisiz değişimden kaynaklanır” (Simmel, 2019, s. 22) sözleriyle açıklamaktadır. Simmel (2019) ayrıca kent hayatının bireyi birçok insanla fiziksel yakınlığa zorlamasının; birey ve öteki arasında ruhsal bir mesafe biçimi oluşturduğunu ifade etmektedir (s. 23-25).

Bireyin kendini dışarıya kapatma eylemi; metropol yaşam biçimine karşı bir tür savunma biçimi olarak ifade edilebilir. Çağımızın belirgin özellikleri olan güvenlik ve korku olgularının, bireyin hem iç hem de dış güvenliği için birçok önlem geliştirdiği görülmektedir. Duygusal mesafe ve kendini dişarıya kapatma gibi eylemler içsel güvenliğin sağlandığ1 düşüncesiyle kendini gösterirken; özellikle metropolün simgesi haline gelen güvenlikli sitelerde dişarıya karşı güvenliğimizi sağladığı düşüncesiyle gün geçtikçe çoğalmaktadır. Günümüzde öne çıkan güvende olmama hissiyatı beraberinde korku duygumuzu azami derecede tetiklerken, çevremizle kurduğumuz ilişsileri de olumsuz yönde etkilemektedir.

Umursamazlık, bezginlik, bunalım gibi psikolojik duygular, kent hayatının bir diğer etkisi olarak karşımıza çıkmaktadır. "Bıkkınlık-belki de başka hiçbir ruhsal fenomen, metropolle böylesine dolaysız bir bağ taşımaz" (Simmel, 2019, s. 23). Bireyin kamusal alanda çevresine ördüğü duvar her ne kadar kendini koruma içgüdüsüyle yaptığı bir eylem olsa da aynı zamanda başka ihtiyaçları engellediği söylenebilir. Bu ihtiyaçlar, iletişim, etkileşim, paylaşma ve sosyalleşme olarak sıralanabilir. Bunların yoksunluğu günümüzde sıkça duyulan yalnızlık, yabancılaşma, depresyon, kayıtsızlık gibi psikolojik duyguların ortaya çıkmasına sebep olabilmektedir. "Psikolog Toru Sato, etkileşimin sağlıklı olduğu bir çevrede bireyin de çevresine etkili bir şekilde uyum sağlamasından, gelişmesinden ve diğer insanlarla/nesnelerle bütünlük içinde yaşamasından söz eder" (Sato'da alıntılandığı gibi Farrelly, 2018, s. 151).

"Kent yalnızca günümüz insanına daha büyük bir oranda iş ve yerleşim olanakları sunmakla kalmaz aynı zamanda dünyanın en uzak yerlerini kendine çeken, türlü bölgeleri, insanları ve etkinlikleri bir düzene göre biçimlendiren, ekonomik, siyasal ve kültürel yaşamın öncüsü ve denetleyicisi konumunda olan bir merkezdir" (Wirth'de alıntılandığı gibi Sevim, 2019, s. 58).

Amerikalı sanatçı Andrea Zittel'in kentin karmaşasından uzak, doğayla ve diğer insanlarla uyum içinde yaşayacağı bir gelecek arzulaması, sanatının temelini oluşturmaktadır. Varoluşun daha iyi anlaşılması için mekânların, nesnelerin ve günlük yaşam eylemlerinin sürekli araştırılması sanat pratiğini oluşturmaktadır. Sanatçı, çalışmalarını bir nevi "yaşam pratiği” olarak adlandırmaktadır.

\section{Resim 1}

\section{A-Z West Project}
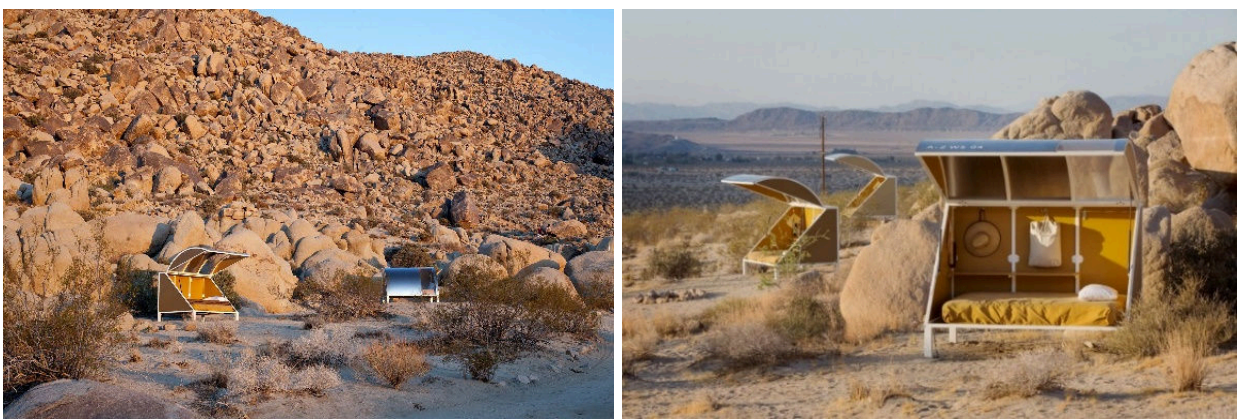

(Zittel, 2000-2003)

Sanatçının “A-Z Batı Projesi” (Resim 1) Joshua Tree Ulusal Parkı'nın yakınında Kaliforniya’nın rakımı yüksek çöl bölgesinde, yetmiş dönüm arazi üzerinde alternatif bir yaşam alanı idealiyle kurulmuş, interaktif bir çalışmadır. Çalışma mimari, heykel, tasarım, mutfak, bahçe ve giyim gibi gündelik yaşamın birçok yönünü kapsamaktadır. Kurulduğu günden itibaren bir nevi araştırma merkezi olarak işlev gören “A-Z Batı Projesi”; Zittel'in hem yaşamının hem de sanat pratiğinin temel meselesi olan "Nasıl yaşamalı?" ve "Hayata anlam veren nedir?" soruları üzerine kurulu bir projedir. Bu soruları yanıtlamak, özgürlük, güvenlik, kent, otorite ve kontrol ihtiyacımız arasındaki karmaşık ilişkileri araştırmayı gerektirmektedir. Sanatçı bu gerekliliği projesi ile birlikte; mekânların, nesnelerin, bugün var olmanın ve bugünün kültürüne katılmanın ne anlama geldiğini sorgulamaktadır.

Yapıtlarını seyirlik bir objeden uzaklaştırarak bireylere deneyim imkânı sunması Zittel'in sanatının başlıca özelliğidir. Her bir kişiye özel yaşam alanı sunan ve kentin yaşam koşullarından koparan deneyimler sunmayı amaçlamaktadır. Bunlar yiyecek kıtlığı, zorlu doğa koşullarında yaşam ve zamansızlık gibi deneyimlerdir. Çalışma, bireyin hem kentin koşullardan etkilenmesine hem de bu koşullardan kaçamayışına odaklanmaktadır. Koşullar ve seçimler arasındaki ilişkiyi, Zygmunt Bauman şu sözlerle ifade etmektedir: "Koşullar, insani seçimlere karşı ilan edilmiş ve benimsenmiş bağışıklıklar zemininde, kendilerini hayat eylemlerinin hedefler ve araçlar oyunundan muaf tutarak insanların seçimlerini sınırlandırırlar" (Bauman, 2018, s. 17). Bu ifadeyle, bireyin seçme 
şansının olmadığı koşullar içinde, bireysel karar vermekten uzak bir yaşam sürdüğü söylenebilir. Zittel, koşullar ve birey arasında kaçınılmaz bağı yaptığı çalışmalarla değiştirmeyi ve bireye farklı olasılıklar sunmayı hedeflemektedir. Sanatçı “A-Z Batı Projesi”yle belli kalıpları ve koşulları yıktığını, bireye özgürleşme imkânı sunan mekanlar yarattığını ifade etmektedir (Colomina ve ark., 2005).

Kentin gözetim kültürü ve kişisel hayatın ihlal edilmesi, sanatçının neredeyse bütün çalışmalarında değindiği bir meseledir. Bireye yeni yaşamlar sunma arzusu, mahremiyete duyduğu önemi görünür hale getirmektedir. Sanatçının kentin kalabalığından ve yoğunluğundan bunalması New York'tan Kaliforniya çölüne taşınmasına/kaçmasına sebep olmuştur. Bu kaçma arzusu sanatçının "A-Z Escape Vehicles-A-Z Kaçış Aracı” (Resim 2) isimli çalışmayı yapmasında önemli bir unsur olarak karşımıza çıkmaktadır.

\section{Resim 2}

\section{A-Z Escape Vehicles}

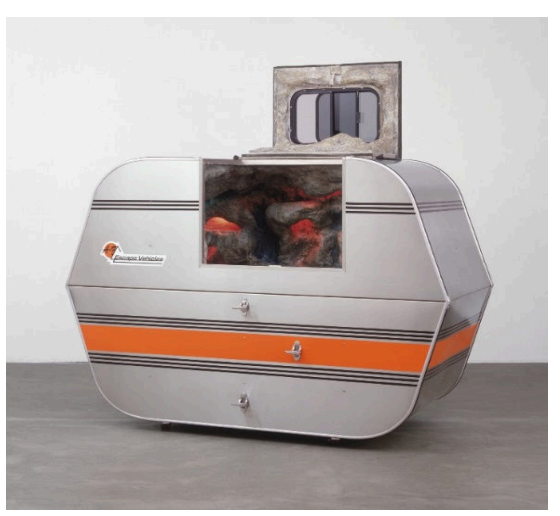

(Zittel, 1996)

“A-Z Kaçış Aracı” Zittel tarafından özelleştirilen ve mobil evden esinlenen bir dizi eserden biridir. Hepsi aynı paslanmaz çelik dış kabuğa sahiptir, ancak her birinin iç mekânı farklıdır. Kişinin ihtiyaçlarına ve özelliklerine göre tasarlanmıştır. Tercihe göre römorklar gibi, bu kapsüller bir arabaya bağlanabilir ve sürülebilir; ancak asıl tasarlanma amacı iç mekâna monte edilmek üzeredir. Sanatçı bu çalışmayı özellikle iç mekâna yapmasının sebebini şu sözlerle açıklamaktadır: "İnsanlar kaçışı hep dışarda aramakta oysa ki dış dünyada bir yere gitmek yerine, kaçmak istediğinde tek yapmanız gereken evin içinde duran bu kapsülün içine kapanmaktır” (McCollum, 2001, s. 11). "A-Z Kaçış Aracı”, yaşanabilir, şekillendirilebilir ve içinde kalan kişinin duygusal yaşamının bir projeksiyonu olarak ifade edilebilir.

Çağdaş sanatta kentleşme konusuna bir diğer yaklaşım örneği olarak Çinli performans ve fotoğraf sanatçısı Liu Bolin'in eserleri gösterilebilir. Sanatçının çalışmaları kent içinde saklanma ve kamufle eylemleri üzerine şekillenmektedir. Eserler heykel, performans sanatı ve fotoğrafçılığı kapsayan sanatsal türlerin ve tekniklerin birleşimidir. Bolin çalışmalarında kent olgusunu ekonomi, siyasi ve toplumsal sorunlar çerçevesinde eleştirel bir yaklaşımla ele almaktadır. En iyi bilinen projeleri arasında "Şehirde Saklanma" serisi 2005 yılında performans sanatı olarak başlayan bir seri fotoğraf yerleştirmedir. Bolin, titizlikle boyanmış insan bedenlerini (genellikle kendi bedenini) kent içinde kamufle olarak ortaya çıkarmaktadır. Kendini boş bir tuval olarak kullanan sanatçı arkasında olan mekânla olabildiğince kusursuz bir şekilde birleşmeyi amaçlamaktadır.

\section{Resim 3}

Hiding in The City-Soijen Village

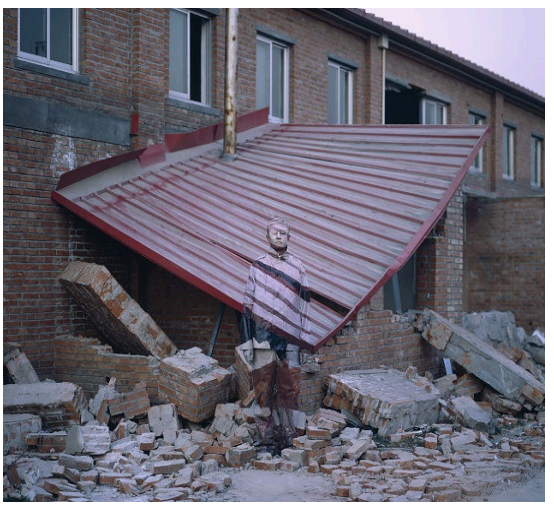

(Bolin, 2006) 
"Şehirde Saklanmak" projesi, 2005 yılında sanatçının stüdyosunun da içinde bulunduğu binanın yıkımıyla başlamıştır (Resim 3). Bu yıkımın karşısında bir şey yapamaması projesiyle birlikte sessiz bir protestoya dönüşmüştür. Sanatçı bu durumu, “16 Kasım 2005’te Suojia köyündeki stüdyom zorla yıkıldı. Buna karşı protestomu göstermek ve sanatçıların şu anki yaşam durumuna daha fazla dikkat çekmek için bu işi yarattım” sözleriyle anlatmaktadır (Smith, 2018). Bolin'in sessiz protestosu sanatsal ifade biçimi olarak tüm çalışmalarında karşımıza çıkmaktadır. Belli yerlere dikkat çekmek için kamufle olmak, önünde durduğu mekân ve nesneleri daha fazla görünür kılmaktadır. "Sanatçı, göstermek istediği yerel ve evrensel kaygıları saklanarak ortaya çıkarma yoluna gitmektedir. Dış tehditlerden korunma stratejisi olan kamuflaj kavramı Liu Bolin'in yapıtlarında, tehdidin kendisini izleyiciye gösterir. İzlenme ve saklanma (kamuflaj) kavramları karşıt iki durumu ortaya koyarken bir gerginlik hissettirir (Mulla, 2020, s. 1379).

\section{Resim 4}

Dangerous Landscapes

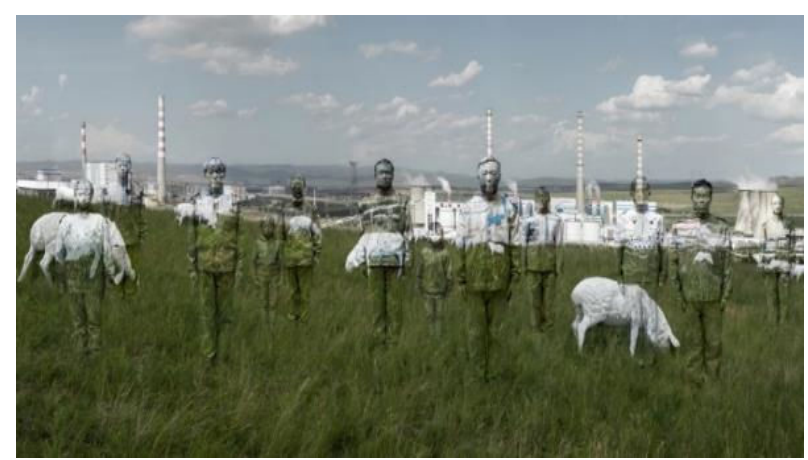

(Bolin, 2016a)

Bolin'in “Tehlikeli Manzaralar” ve "Kış Gündönümü” (Resim 4-5) isimli eserleri, insan bedenlerinin fabrikalara ve cılız ağaçlara dönüştüğü görsellerden oluşmaktadır. Çalışmalarda kentin oluşturduğu hava kirliliği, doğanın katledilmesi ve diğer canlı türlerinin tehlike altında olma durumu gibi birçok konu ele alınmaktadır. Burada bireyciliğin ve araçsal aklın; insanın kendi yaşam alanı üzerinde açmış olduğu tahribat ilişkisi gözlemlenebilir. Ayrıca kentin ileri sanayi toplumu tarafından uğradığı deformasyona ve insan eylemlerinin zararlı sonuçlarına dikkat çekmektedir. Liu Bolin, “Tehlike Manzaralar” serisini “adam kendi ortamını yok ederek gelişir. Görkemli uygarlık için ödemesi gereken bedel, hayvanlar alemine ait olduğunun bilincini yitirmesidir. İnsan, elde ettiği gelişmeden yararlanarak kendi hırsından mezarını kazmaktadır” sözleriyle ifade etmektedir (Simon, 2017).

\section{Resim 5}

\section{Dongji (Winter Solstice)}

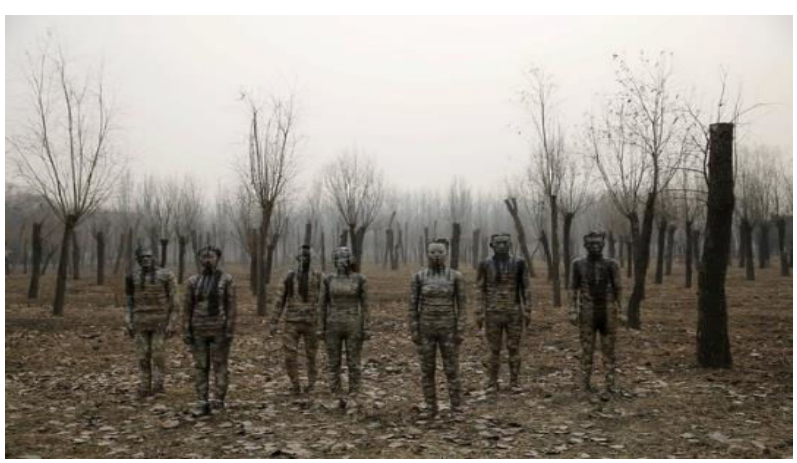

(Bolin, 2016b)

Bolin'in sanat pratiği, içinde yaşadığı toplumun olumsuzlukları ve çağın sorunları üzerine şekillenmektedir. Çalışmalarında kamufle olarak görünmez olma durumundaki ısrarcı tavrı ve bu ısrarın temelinde birey olarak yaşam mücadelesi ile ilişkili olduğu görülmektedir. Sanatçı, tehlikede olan bir insanlık vizyonundan yola çıkmakta ve bizi çağın teknolojik, ekonomik ve politik yapılarını sorgulamaya davet etmektedir. 


\section{Resim 6}

Tek Kişisin Sana Yeter

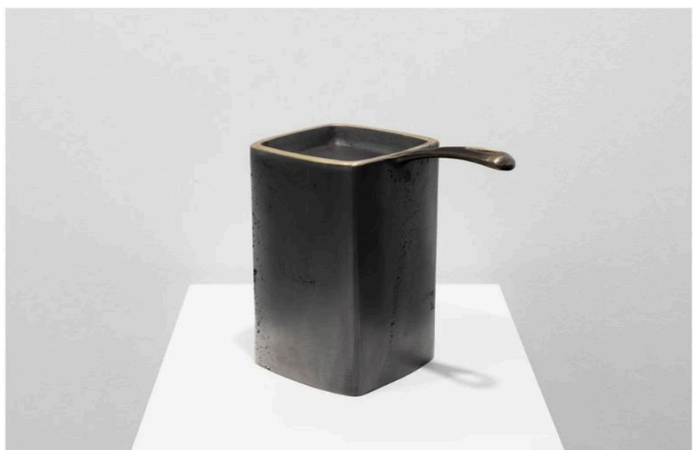

(Özcan, 2016)

Yasemin Özcan'ın 2016 yılında gerçekleştirdiği “Saadet Çıkmazı” isimli sergisinde yer alan “Tek Kişisin Sana Yeter" çalışması, (Resim 6) sanatçının boşandıktan sonra sıkça duyduğu tek kişisin sana yeter cümlesi üzerine şekillenmiştir. Seramik malzemeden üretilen tek kişilik tava, çağımızın yalnızlık, boşanma ve aile ilişkilerini konu edinmektedir. Özcan çalışmalarında görülen ironi ve mizahı; bir tür savunma mekanizması olarak kullanmakta ve ondan güç alarak içinde bulunduğu durumları dişa vurabildiğini ifade etmektedir (Ezer, 2016).

Kentleşmeyle gelişen aile modellerinin, kalabalık aileden çekirdek aileye ve hatta tek kişilik yaşam biçimine dönüşmesi beraberinde yalnızlığın ruhsal ağırlığını da getirmektedir. Tavanın tek kişilik bir nesnenin aksine oldukça büyük ve ağır bir kütle yapısına sahip olması, yalnızlığın bu fiziksel ve ruhsal ağırlığını görünür kılmaktadır. Ayrıca çalışma, ataerkil bir toplumda yalnız ve boşanmış bir kadın olarak yaşamanın zorluğuna da işaret etmektedir. Bekar olmanın kendi coğrafyasında yarım olarak algılanması ve aza kanaat etmek zorundaymış gibi davranılması çalışmanın ismi üzerinden aktarılmaktadır. "Tek Kişisin Sana Yeter” birey kelimesinin sözcük anlamının (tek bir fert) hala günümüzde karşılık bulamaması ve birey olamamakla ilgili temel sorunu ortaya koymaktadır. Sonuç olarak, sanatçı kişisel hikayesinden yola çıkarak yalnızlık, bekâr yaşam ve birey kavramlarını ele almaktadır.

\subsection{Tüketim Sarmalı}

Modern çağ toplumlarının üretici yönünün günümüzde üretimden ziyade tüketim alışkanlığına dönüştüğü söylenebilir. Çağımızın tüketim nesnelerinin artan dolaşımı, bireyin mutluluk arayışında tüketime başvurduğu yaygın bir eğilim olarak karşımıza çıkmaktadır. Pazar arama verilerini kayıt altında tutarak ve isteklerimize hızlı öneriler getirerek bizi tüketim sarmalı içine çekmektedir. Elizabeth Farrelly, kişisel mutluluğun satışa sunulan bir işletmeye dönüştüğünü; kitapevlerinde nasıl mutlu olunacağını anlatan kitapların gün geçtikçe çoğalması örneği üzerinden vurgulamaktadır. Piyasaların, "satın alın çünkü hakkediyorsunuz" sloganıyla tüketimi meşrulaştırdığına dikkat çekmektedir. Yazar reklamların, mutluluğu ve arzuları tüketerek doyum sağlama durumuna indirgediğini ve arzumuzu tatmin etmenin sadece bir hak değil, aynı zamanda bir tür ödev olduğunu kabul ettirdiğini ifade etmektedir (Farrelly, 2018, s. 19). İnsanların arzuları artmaya devam ettikçe, tüketimin de var olacağı kaçınılmazdır. Coşkuyla istenen bir eşyanın, onu satın alıp birkaç gün kullandıktan sonra bizi daha az heyecanlandırması arzu ve tüketim deneyimine dayalı bir bilgi vermektedir. Günümüz yaşam biçimleri, iletişim araçlarıyla hareketlilik ve değişkenlik gösterebilmektedir. Nesneler ve görüntüler reklamlar tarafından yönlendirilip bireyi harekete geçiren kitlesel bir araç konumuna yerleşmiştir. Dolayısıyla ihtiyaçların oluşması ve zorunlu hale gelmesi, bireyin denetimi dışında gerçekleşebilmektedir.

Şüphesiz insan hayatta kalabilmek için bir takım temel ihtiyaçları doğrultusunda tüketmek zorundadır. Ancak çağımızın tüketim anlayışı, temel ihtiyaçlardan ziyade tüketilen her şeyin ihtiyaç olduğu anlayışa dönüşmüştür. Jean Baudrillard “Tüketim Toplumu” isimli kitabında, ihtiyaç olgusunu nesne ve tatmin üzerinden çözümlemeye gider. Nesnelerin yerinin doldurulamaz olduğu nesnel işlev alanlarının dışında, yan anlamlar alanında birçok nesneyle yer değiştirebilir hale geldiğini ifade etmektedir. Buna örnek olarak çamaşır makinesinin işlevsel anlamı yanı sıra konfor ve prestij anlamları taşımasından bahsetmektedir. Tüketim alanının bu ikinci anlamda varlık gösterdiğini ve aynı yan anlamı taşıyan her tür nesnenin çamaşır makinesinin yerine geçebilmesinin ihtiyaca bağlı olmadığını, "Bu tam olarak nesnelerin başka bir şeye cevap vermesidir" sözleriyle ifade etmektedir (Baudrillard, 2008, s. 89-90). Baudrillard'ın bu sözünden yola çıkarak, nesnelerin temel ihtiyaçların ötesinde yeni anlamlar taşıması, tüketim olgusunu da farklı bir boyuta taşımaktadır.

Çağımızın ihtiyacın yanı sıra hazza bağlı tüketim deneyimi, ürünlerin nesnel bir varlıktan öznel sembollere dönüşmesinde etken bir rol oynamaktadır. Günümüzde bireyin arzu ettiği ürünü alması ona fayda sağlamasından daha çok tatmin sağlamasıyla ön plana çıkmaktadır. Reklam, imaj, statü, haz alma gibi olguların desteğiyle 
nesnelere öznel ve soyut anlamlar yüklenmesi yaşam deneyimini şekillendirmektedir. Tüketici sahip olduğu nesneyle ve ona yüklenen yan anlamla birlikte, kendi yarattığı dünyada hayal ettiği şeye bürünebilir. Bu durum bireyin soyut varoluşunu nesnel dünya içinde gerçekleştirme isteminin bir sonucu olarak karşımıza çıkmaktadır.

\section{Resim 7}

Yeni Bir Tür 1

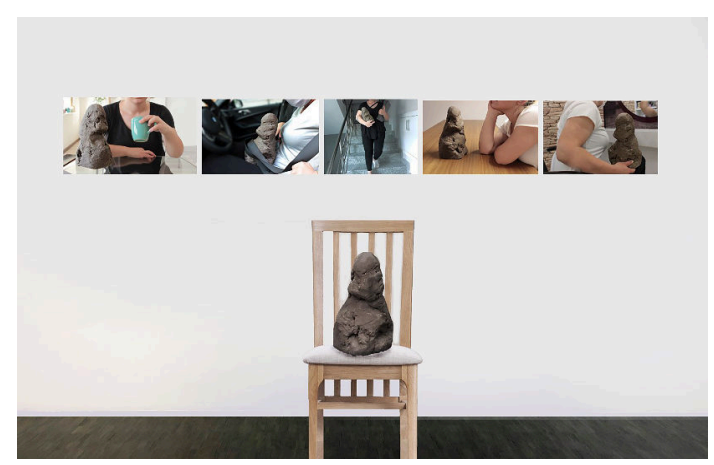

(Nükte Dinçer, 2021)

"Yeni bir tür" (Resim 7) isimli çalışmanın oluşumu birey ve nesne ilişkisi üzerine yapılan araştırmaların bir sonucudur. Proje amorf bir formu (Resim 8) farklı mekân ve koşullarda yanında taşıyan bireyin, bakış açısıyla kurgulandığı bir fotoğraf yerleştirmedir. Çalışma bu yerleştirmeyle bireyin nesneyle kurduğu diyalektiği ifade etmeyi amaçlamaktadır. Yerleştirmede yer alan amorf form, bu dönemin modası olan herhangi bir gündelik kullanım nesnesinin temsili niteliğindedir. Dolayısıyla tek bir nesneye referans vermeyen çalışma, amorf bir formla karşımıza çıkmaktadır.

\section{Resim 8}

Yeni Bir Tür 2
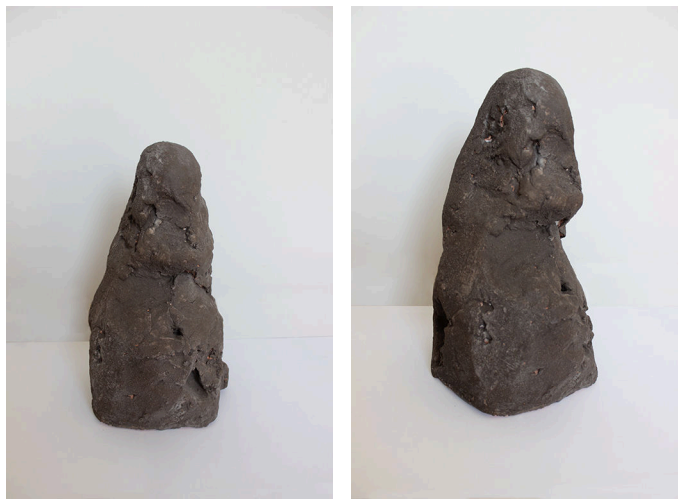

(Nükte Dinçer, 2021)

\section{Resim 9}

Yeni Bir Tür 3
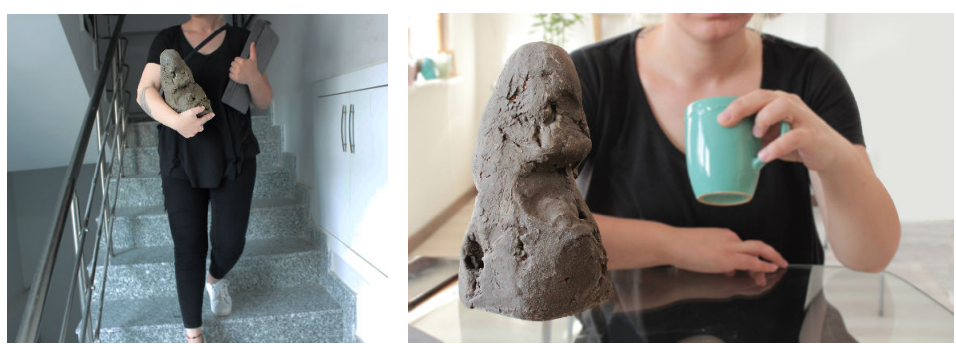

(Nükte Dinçer, 2021)

Seride formun yer yer taşınması (Resim 9), masa üzerinde durması veya kişinin kucağında oturması (Resim 10), günümüzde nesnelerin meta değil, canlı birer organizmaya dönüşmesi metaforuyla ilişkilidir. Bu metafor, Simmel'in "Modern Kültürde Çatışma” adlı kitabında geçen "bireyin soyut varoluş çabası" söylemi üzerine oluşturulmuştur. Simmel popüler bir nesneye sahip olmayı, bireyin hem toplumla bütünleşme hem de toplum içinde farklılaşma ikilemiyle ortaya koymaktadır. Bireyin toplum içinde bir yanda devamlılığa, birliğe, eşitliğe, 
benzerliğe diğer yanda özgüllüğe ve biricikliğe duyduğu ilgiden bahsetmektedir (Simmel, 2019, s. 13). Çalışmada görülen amorf formla, nesnenin sınıfsal bir anlam kazanması ve değer sistemine göre sahip olma işlevi vurgulanmaktadir.

\section{Resim 10}

Yeni Bir Tür 4

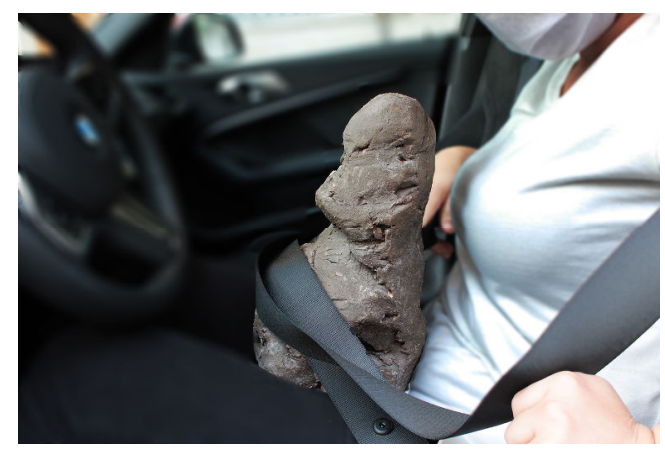

(Nükte Dinçer, 2021)

\section{Resim 11}

Yeni Bir Tür 5

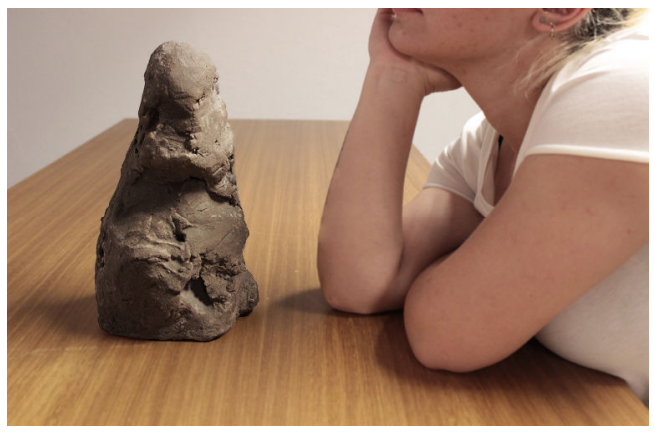

(Nükte Dinçer, 2021)

Nesnelerin işlevsel özelliklerinin kaybolduğu hatta insanlar gibi seçkin, haz uyandıran ve saygı duyulan bir özne olarak konumlandırıldığını söylemek yanlış olmayacaktır. Guy Debord'un Gösteri Toplumu'ndaki insanlar, "kendi üretimleri olan meta'ya kendisinden daha çok değer yüklemeye başlayarak kendisini meta'nın bir gösterim alanı olarak sunmaya yönelmiştir" (Tomak ve ark., 2015, s. 71). Bu yaklaşımı "Yeni Bir Tür" isimli çalışmada şekilsiz ve işlevsiz bir nesnenin anlamsız bir şekilde bir yerden diğerine taşınması veya korunmaya çalışılmasıyla gözlemek mümkündür. Çalışmada kullanılan mekânlar ve kurgu, özneleştirilen nesnelerin, nesneleşen öznelerin yerini aldığını ve nesnelerin gün geçtikçe saygınlık ve statü kazandığı düşüncesine işaret etmektedir.

\section{Resim 12}

The Faith in Shopping

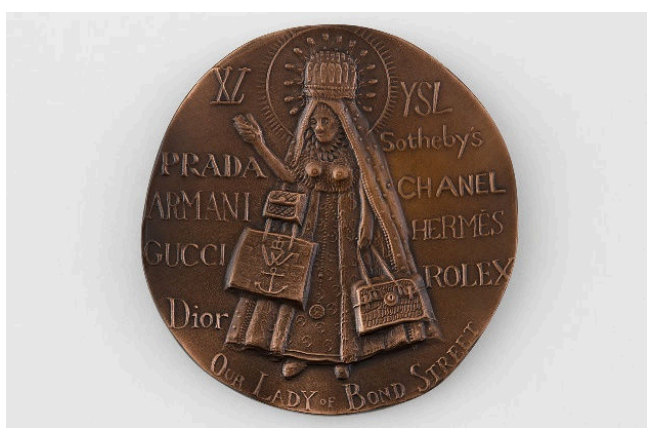

(Perry, 2008)

İngiliz sanatçı Grayson Perry, eserlerinde sanat tarihini, sanat dünyasını ve tüketim kültürünün ilişkisini tartışmaktadır. "Alışverişe İnanç” isimli çalışma (Resim 12) bir marka adını veya sembolü 17. yüzyıl armaları ve sembolleriyle birleştirerek 21. yüzyılın materyalist kaygılarını yansıtmaktadır. Çalışmada görülen Meryem Ana imgesi, kutsal bir tasvirden ziyade farklı markalarla çevrili "Bond Sokağının Leydisi" olarak karşımıza 
çıkmaktadır. Çă̆ımızda neredeyse hiçbir nesnenin işlevsel özelliğiyle satışa sunulmaması, üzerinde ünlü bir marka ambleminin yeterli olması; bireysel statü, prestij, algılanan refah ve yaşam kalitesi tahsisidir. Dolayısıyla bireyin, tüketime kaliteli ve iyi bir yaşam umuduyla başvurduğunu söylemek günümüz tüketim anlayışının kaynağı olarak düşünülebilir. Bu doğrultuda çalışma değer sisteminin ve tüketim olgusunun sorgulamasına 1şık tutmaktadır.

\section{Resim 13}

We Are What We Buy
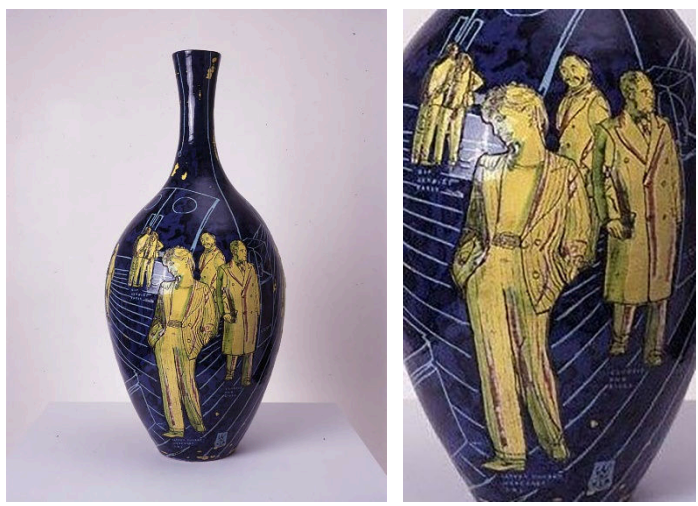

(Perry, 2008)

Çağımızın ihtiyacın yanı sıra hazza bağlı tüketim deneyimi, sanatın tüketim toplumu içinde dönüşmesinde etken bir rol oynamaktadır. Bu bağlamda günümüzde sanatın hızla tüketilmesi ve bir meta kavramına dönüşmesi Perry'nin, "Ne Satın Alıyorsak Oyuz" (Resim 13) çalışmasında eleştirilmektedir. Sanatçı, sanat dünyasını ve bu baskın kültürün gösterişçiliğini kendi tarzıyla hicvetmektedir. Şekillendirdiği geleneksel çömlek formlarının aksine, üzerinde betimlediği çağdaş sanat dünyası ve tüketicilerin klişe durumları; geçmiş ve bugünü, üst ve alt kültürü çakıştırmaktadır. Vazonun üzerindeki karakterlerin sergilenen eseri veya tüketim nesnesini izlerken ciddi yüz ifadeleri dikkat çekmektedir. Ciddiyetle bakan ve üstün bir hava ifade etmek için burunlarını gökyüzüne ulaştıran bu figürler; kültür uzmanı tavrıyla dolaşmaktadır. Perry'nin nazik ama kurnazca kurguladığı mizahın altında, tüketim toplumuna yaptığı eleştirel tavır dikkat çekmektedir. Sanatçı bu eleştirisini "Onları satın alacak insanları savuşturan birçok iş yaptım... ama bu onları durdurmadı. İnsanlar kendilerini gülünç görmeyi severler” (Hattenstone, 2014) sözleriyle dile getirmektedir.

\section{Resim 14}

Waste After Waste

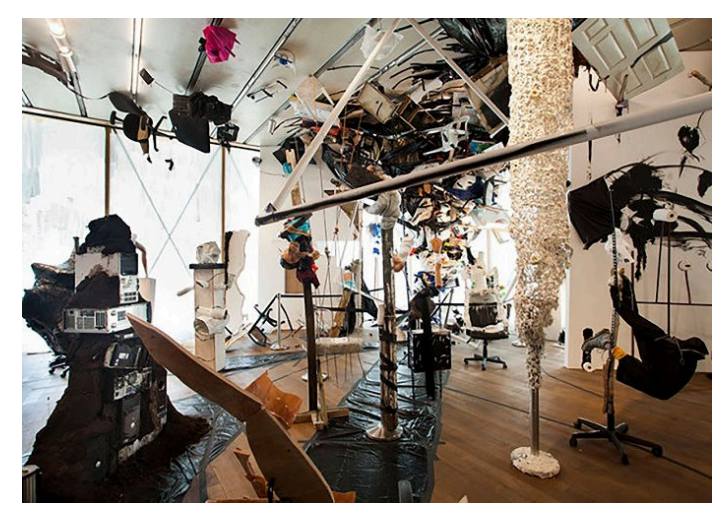

(Bianchi, 2015)

Arjantinli sanatçı Diego Biachi'nin son yıllarda yapmış olduğu eserleri, tüketim toplumunun görsel ve kaotik izlerini taşımaktadır. 2015 yılında gerçekleştirdiği "Waste After Waste / Atık Üstüne Atık” (Resim 14) isimli sergisi tüketim ve tüketici israfını ele alan bir dizi çalışmadan oluşmaktadır. Sanatçı buluntu ve atık malzemeleri, eserleri aracılığıyla görünür hale getirmekle ilgilenmektedir. Her gün giderek fazlalaşan atıklar üzerine düşünmemizi ve nesnelerle kurulan yeni ilişki türlerini sorgulatmayı amaçlamaktadır. 2001 y1lında Arjantin hükümetinin para birimini düşürmesi ve sonucunda gerçekleşen ekonomik kriz, sanatçının çalışmalarında önemli bir rol oynamaktadır. Yaptığı sıra dışı heykeller ve yerleştirmeler; yaktığı, sardığ1 veya birbirine yapıştırdığ 1 buluntu nesnelerden oluşmaktadır. Nesneleri bulduğu şekilde kullanmaktan ziyade onları dönüştürerek çalışmalarına dahil etmektedir. 


\section{Resim 15}

Market or Die

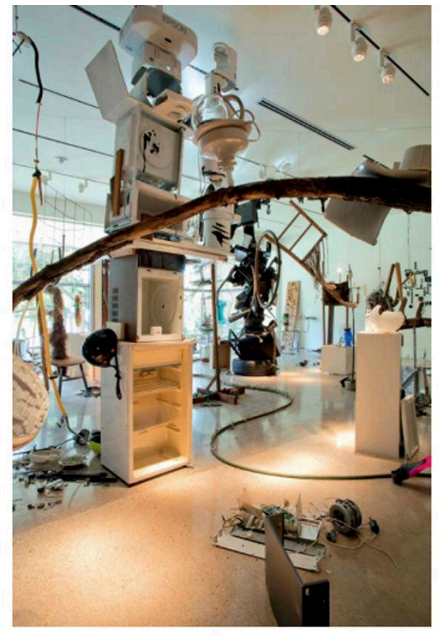

(Bianchi, 2013, s. 392)

Sanatçının 2013 yılında gerçekleşen 13. İstanbul Bienalinde sergilediği "Market or Die- Ya Pazar Ya Ölüm" (Resim 15) çalışması günümüz pazarının bir manzarasını oluşturmaktadır. "Dükkân vitrinlerinin veya sokak tezgâhlarının yapısını eserine uyarlayan sanatçı, bulunmuş nesnelere veya "alt sınıf" olarak nitelendirilebilecek döküntülere sığınak oluşturan sürrealist bağlantılar tasarlıyor" (Villa, 2013, s. 393). Neoliberal toplumun tüketimle oluşturduğu karışıklığı ve bireyin tüketimde geldiği son noktayı gündelik atıklardan oluşan yerleştirmeyle gözler önüne sermektedir.

Bireyin nesnelere bağlılığıyla ve onların gündelik yaşamı nasıl etkilediğiyle ilgilenen Bianchi, nesneleri yeni bir form içinde sunmaktadır. Atık olan nesneleri görünmezlik bağlamından çıkararak kaotik benzeri bir ortamda heykel grupları olarak yeniden konumlandırmakta ve izleyiciye israfın varlığını işaret etmektedir. Bireyin nesneyle olan ilişkisinin sonucu yerleştirmenin kaotik ortamında görünürlük kazanmaktadır. Bireyin tükettikçe var olacağı, mutlu ve tam hissedeceği inancıyla tüketmesi ve bu yolla var olma mücadelesinin imkansızlığı, çalışmanın kaotik görüntüsüyle örtüşmektedir. Sonuç olarak Bianchi yapmış olduğu yerleştirmeyle, bireyin varoluş çabasını ve günümüz tüketim alışkanlığını çarpıcı şekilde sunmaktadır.

\section{Sonuc}

Bu çalışmada, kent ve tüketim toplumunun etkilerinden yola çıkarak bireyin gündelik yaşam pratikleri, psikososyal dünyası, ilişkileri ve iletişim biçimleri üzerine kurulu bir yol izlemiştir. Bireyciliğin kendine yeten ve özgür birey ideolojisi araştırmanın eleştiri alanını oluşturmaktadır. Birey idealinin daha iyi bir gelecek vaadini ve bireycilik ideolojilerini günümüz koşullarında tartışmak amaçlanmıştır. Modern çağla birlikte dünyada yaşanan dönüşüm sanat alanında da köklü değişimlere sebep olmuştur. Her çağın sanatçısı, içinde bulunduğu dönemin değişimiyle sanata yön vermiş ve sanatın bugün geldiği noktaya ulaşmasında katkı sağlamıştır. Sanatçının içinde yaşadığı toplum ve kültürle olan etkileşimi, kaçınılmaz olarak eserlerine de yansımaktadır. "Daha önce hiç olmadığı kadar çok sayıda sanatçı, içinde yer aldığımız değişken koşullara tepki olarak toplumsal sorunlara kafa yormaktadır" (An ve Cerasi, 2021, s. 19). Çağın sanatçıları olumlu ya da olumsuz anlamda etkilendiği olayları yeni anlatım biçimleri geliştirerek izleyene aktarmaktadır.

Bu kapsamda Andrea Zittel, Liu Bolin, Grayson Perry ve Diego Biachi'nin eserleri, 90'lar sonrası kentleşme ve tüketim fenomenleri üzerinden ele alınmaktadır. Ayrıca tüketim toplumu içinde bireyin nesneyle olan ilişkisi kişisel bir projeyle irdelenmektedir. Makalede sanatçıların farklı yaklaşımları göz önünde bulundurularak, 21. yüzyılın değişken koşulları karşısında bireyin yaşadığı sorunlara ve dönüşüme yer verilmiştir. Sanatçıların, bireyin içinde bulunduğu sosyal ve gündelik pratiklerin değişimleri üzerine yaptığı üretimler; genel olarak bireyi kentleşme ve tüketimin sonucunda gelişen mevcut endişeler içinde konumlandırmaktadır.

Günümüz neoliberal anlayışın, ekonomik, sosyal ve kültürel alanda bireyin taleplerini karşılamadığı çağdaş sanatta eleştirel bir tavırla karşımıza çıkmaktadır. Bolin'in eserlerinde hızla değişen yaşam alanı ve bireyin kent içinde kaybolması konu edilirken, Grayson Perry ve Diego Bianchi'nin eserlerinde tüketim toplumunun sanatı metalaştırması ve bireyin israfa yönelik tutumu eleştirilmektedir. Andrea Zittel ise bireyin günümüzde yaşadığ zor hayat koşullarına alternatif olarak yeni yaşam alanları oluşturmakta ve bireyi bu deneyime davet etmektedir.

Birey idealiyle ortaya çıkan bireycilik ve araçsal aklın sonucu, günümüz ilişkilerinin ben merkezci ve karşılıklı çıkar ilişkisi olarak geliştiği söylenebilir. İnsanlık birey idealinin ortaya çıktığı üç yüz yıldan sonra; doğanın ve 
diğer canlıların gelir karşılığı yok edildiği, birey idealinin temel anlayışı olan "Hümanizmin” merkeze aldığ insanın, bir bütünün parçası olduğu fikrinin karşılık bulmadığı bir dünyada yaşamaya devam etmektedir. Bireyin bilim ve aklın ışı̆̆ında iyi bir geleceğe ulaşacağı vaadi; kentin hayat mücadelesinde kaybolan, gelir kaygısıyla sürekli çalışan, yalnızlaşan, tüketim toplumu içinde hem tüketerek hem de tükenerek yitip giden bir bireye dönüşmüştür. Çağdaş sanatta yaşanan dönüşümü görünür kılan, altını çizen eleştirel tavrını koruyan sanatçılar güncel tartışmaya katkı sağlamaktadır. Her ne kadar sanatın da tüketim toplumunda metalaşması bir eleştiri konusu olsa da sanatçıların bireysel seslerinin topluma ve bireye dokunma ihtimali taşımaktadır. Bu bağlamda çağdaş sanatta birey ve toplum eleştirisi üzerine yapılan üretim, kalabalıkların içindeki bireysel deneyim üzerinden kolektif bir algı yaratma ve dönüştürme potansiyelini koruduğu düşünülmektedir.

\section{Kaynakça}

Adorno, T. W., \& Horkheimer, M. (2014). Aydınlanmanın diyalektiği felsefi fragmanlar. (N. Ülner ve E. Öztarhan Karadoğan, Çev.). Kabalcı Yayınevi.

An, K., \& Cerasi, J. (2021). Kim korkar çağdaş sanattan. (M. Üstünipek Çev.). Hayalperest Yayınevi.

Baudrillard, J. (2008). Tüketim toplumu. (H. Deliceçaylı ve F. Keskin, Çev.). Ayrıntı Yayınları.

Bauman, Z. (2018). Iskarta hayatlar modernite ve safraları. (O. Yener, Çev.). Can Yayınları.

Beck, U., \& Beck-Gernsheim, E. (2002). Individualization: Institutionalized individualism and its social and political consequence. Sage Publications.

Berman, M. (2013). Katı olan her şey buharlaşıyor. (Ü. Altuğ ve B. Peker, Çev). İletişim Yayınları.

Bianchi, D. (2013). Market or die [Fotoğraf]. 13. Ístanbul Bienal Rehberi (s. 392) içinde. Yapı Kredi Yayınları

Bianchi, D. (2015). Waste after waste [Fotoğraf]. Pamm. https://www.pamm.org/exhibitions/project-gallerydiego-bianchi

Bolin, L. (2006). Hiding in the city-Soijen Village [Fotoğraf]. Galeria Paris. http://www.galerieparisbeijing.com/ 14-liubolin-hidinginthecity-suojiavillageno2/

Bolin, L. (2016a). Dangerous landscapes [Fotoğraf]. Bessard. https://editionsbessard.com/product/chinadangerous-landscape-limited-edition-of-800-copies-signed-c-print/

Bolin, L. (2016b). Dongji (Winter solstice) [Fotoğraf\}. Artnet. https://news.artnet.com/art-world/liu-bolin-airpollution-in-china-398028

Colomina, B., Wigley, M., \& Zittel, B. (2005). A-Z drive-Thru conversation. http://www.yorku.ca/yamlau/3001k/ andrea $\% 20$ zittel $\% 20$ conversation.pdf

Ezer, B. (2016, Kasım 16). Tek kişinin yapabileceği herşey. Unlimited. https://www.unlimitedrag.com/post/2016/ 11/16/tek-ki\%C5\%9Finin-yapabilece $\%$ C4\%9Fi-her-\%C5\%9Fey

Farrelly, E. (2018). Mutluluğun sakıncaları. (E. Gökyaran, Çev.). Yapı Kredi Yayınları.

Hattenstone, S. (2014, Ekim 8). Grayson Perry: Just because you don't have a drees on doesn't stop you being a tranny. The Guardian. https://www.theguardian.com/artanddesign/2014/oct/04/grayson-perry-dresstranny-art-who-are-you-tv

Karamolla, M., \& Kiriş Yılmaz, N. (2020). Adorno ve Horkheimer'ın araçsal akıl eleştirisi. Journal of History School, 48(13), 3562-3580. http://dx.doi.org/10.29228/Joh.39345

Löwy, S., \& Sayre, R. (2015). Isyan ve melankoli-Moderniteye karşı Romantizm. (I. Ergüden, Çev.) Alfa Yayınları.

McCollum, A. (2001, Aralık 5). Andrea Zittel in conversation with Allan McCollum. http://allanmccollum.net/allanmcnyc/amcpdfs/McCollum-Zittel_Interview.pdf

Mulla, G. (2020). Şehirde saklanan sanatçı: Lui Bolin. Idil Dergisi, 73(9), 1379-1388. https://doi.org/10.7816/idil09-73-02

Nükte Dinçer, M. (2021). Yeni bir tür [Fotoğraf]. Melike Nükte Dinçer Fotoğraf Arşivi

Özcan, Y. (2016). Tek kişisin sana yeter [Fotoğraf]. Unlimited. https://www.unlimitedrag.com/post/2016/11/16/ tek-ki\%C5\%9Finin-yapabilece $\%$ C4\%9Fi-her-\%C $5 \% 9$ Fey

Perry, G. (2008a). The faith in shopping [Fotoğraf]. Artsy. https://www.artsy.net/artwork/grayson-perry-forfaith-in-shopping-1 
Perry, G. (2008b). We are what we buy [Fotoğraf]. Saatchi Gallery. https://www.saatchigallery.com/artist/grayson perry

Sevim, Z. (2019). Kent-kültür-birey: Döngüsel süreç. Akademik Sosyal Araştırmalar Dergisi, 91(7), 53-62. http://dx.doi.org/10.16992/ASOS.14890

Simmel, G. (2019). Modern kültürde çatışma. Sunuş: Frisby, David. Georg Simmel-Modernitenin ilk sosyoloğu. (T. Bora, U. Özmakas, N. Kalaycı ve E. Gen, Çev.). İletişim Yayınları.

Simon, E. (2017, Eylül 19). Expo photographie contemporaine: Lui Bolin "revealing disappearance". Actuart. http://www.actuart.org/2017/09/expo-photographie-contemporaine-liu-bolin-revealingdisappearance.html

Smith, A. (2018, 29 Haziran). Meet the artist who literalyy puts himself into his work. Lonely Planet. https://www.lonelyplanet.com/articles/artist-liu-bolin-vanishing-point

Tomak, A., Seylan, A., Yazar, T., \& Turkaya, A. (2015). Tüketim çağında özne-nesne diyalektiği ve değişen anlam. Medeniyet Sanat, IMÜ Sanat ve Tasarım Fakültesi Dergisi, 2(1), 65-74 https://dergipark.org.tr/tr/download/article-file/150670

Touraine, A. (1995). Modernliğin eleştirisi. (H. Tufan, Çev). Yapı Kredi Yayınları.

Villa, J. (2013). 13. Istanbul Bienali Rehberi. İstanbul Kültür Sanat Vakfı ve Yapı Kredi Yayınları.

Zittel, A. (1996). A-Z Escape Vehicles [Fotoğraf\}. The Museum of Modern Art. https://www.moma.org/audio/ playlist/1/222

Zittel, A. (2000-2003). A-Z West Project [Fotoğraf]. Deezen. https://www.dezeen.com/2016/08/19/wagon-stationencampment-andrea-zittel-tinycamping-pods-creative-refuge-california-desert/ 